\title{
Performance of Six- and Ten-story Reinforced Concrete Buildings Designed by using Modified Partial Capacity Design (M-PCD) Method with 70\% Shear Force Ratio
}

\author{
Pudjisuryadi, P..$^{*}$, Wijaya, F.1, Tanuwijaya, R.1, Prasetyo, B.C. ${ }^{1}$, and Lumantarna, B. ${ }^{1}$
}

\begin{abstract}
One design alternative of earthquake resistant building is Partial Capacity Design (PCD) method. Unlike the commonly used capacity design method, PCD allows a safe failure mechanism which is called partial sidesway mechanism. In this mechanism, all beams and some columns are allowed to experience plastic damages while some selected columns are designed to remain elastic (called elastic columns). A new approach to predict the required strengths needed to design each structural member, called modified-PCD (M-PCD) is proposed. In this research sixand ten-story reinforced concrete buildings were designed using M-PCD, and their seismic performances are investigated. The base shear force resisted by the elastic columns was set to approximately $70 \%$ of the total base shear. Both nonlinear static procedure (NSP) and nonlinear dynamic procedure (NDP) are used to analyze the structures. The results show that the expected partial side sway mechanism is observed, and the drifts of the buildings are acceptable.
\end{abstract}

Keywords: Modified partial capacity design; partial side sway mechanism; reinforced concrete; seismic design.

\section{Introduction}

In the design of earthquake resistant structures, one alternative of the capacity design method [1] is partial capacity design (PCD) method. The PCD method allows a safe failure mechanism proposed by Paulay and Priestley [2] which is called the partial sidesway mechanism. In this mechanism, some of columns are allowed to experience plastic damages while other columns (elastic columns) are intended to remain elastic during target earthquake. The challenge of this concept is how well the prediction of structural members' required strength. Early PCD method proposed that elastic columns could be designed by using a single magnification factor which scales up their internal forces from a design earthquake. Seismic reduction factor of 8.0 was used to define the design earthquake with the assumption that the structure possesses good ductility. However, some studies showed that the performance of the method was somehow inconsistent. Based on the early study that used the single magnification factor to design the elastic columns, the test results showed that plastic hinges still occurred on the elastic column in the nonlinear time history analysis [3].

\section{${ }^{1}$ Department of Civil Engineering, Petra Christian University, Л. Siwalankerto 121-131, Surabaya 60236, INDONESIA \\ "Corresponding Author, Email: pamuda@ petra.ac.id}

Note: Discussion is expected before November, $1^{\text {st }} 2021$, and will be published in the "Civil Engineering Dimension", volume 24, number 1, March 2022.

Received 25 September 2021; revised 29 September 2021; accepted 30 September 2021.
Other studies that used the single magnification factor with other variations of building that have vertical setback showed unsatisfactory results because the partial side sway mechanism was not achieved effectively [4,5]. A more accurate approach in predicting the required strengths may be one of the answers to improve PCD method.

Recently, Tanaya [6] proposed a new approach in predicting the required strength to design the elastic columns. This new approach is called Modified-PCD (M-PCD). The M-PCD suggests the use of two structural models to predict the required strengths needed to design the structural members. The first structural model was used to design elements which are allowed to yield during major earthquakes. This model was subjected to earthquake with seismic reduction factor $\mathrm{R}=8$ (design earthquake). The second structural model was modified from the first one by reducing stiffness of members that may develop plastic hinges, and subjected to a target earthquake $(\mathrm{R}=1.6)$. This second model was used to design the elastic columns. Early test showed promising results, most structure showed the expected partial sidesway mechanism and the drifts are well below the maximum values set by FEMA 273 [7]. However, more tests are needed to further develop and conform the effectiveness of this new approach.

In this research, improvement of M-PCD proposed by Tanaya [6] is suggested. The second model is not subjected to full target earthquake, instead it is subjected by the difference between target earthquake and design earthquake used in the first model. This is logical, since after some members develop 
plastic damages, only the remaining earthquake load (beyond design earthquake) will be distributed according to structural responses of the second model. With this improvement, buildings similar to Tanaya's research are re-designed and investigated.

\section{Model and Design of the Buildings}

SAP2000 software [8] is used to model the buildings. The buildings are assumed to be located in Surabaya resting on soil with Site Class E, and intended as office buildings. The applied gravity loads were according to SNI 1727:2013 [9]. The building plans and elevation views can be seen in Figure 1.

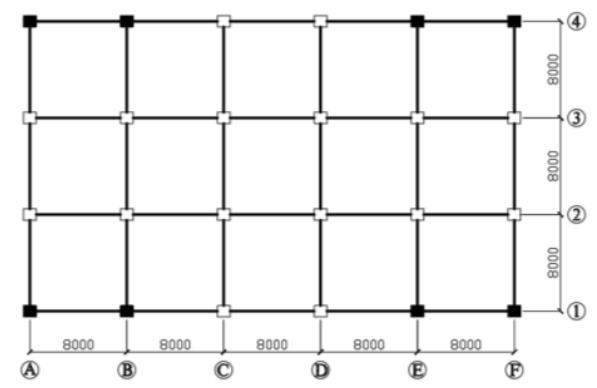
=Plastic Column

(a)

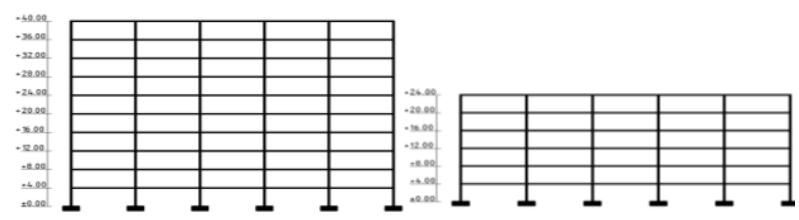

(b)

Figure 1. Observed Structures: (a) Plan View; (b) Elevation View

In this study, the ratio of shear force resisted by elastic columns with respect to the total base shear is approximately set as large as $70 \%$, resulting in the use of eight elastic columns (Figure 1a). As mentioned in the introduction, two structural models are used in this approach. Illustration of these two structural models as well as seismic load (based on SNI 1726:2012 [1]) subjected to each model are shown in Figure 2. The modification factors (R) of 8.0 and 1.6 are chosen with the assumptions that the damaged frame members possess good ductility and elastic columns remain elastic, respectively. The stiffness reduction to simulate plastic damages is done by breaking the elements into three parts. Two of the parts are located close to element supports with the length of $0.5 h_{\text {element }}$ (typical plastic hinge region), which flexural stiffnesses are reduced to model plastic hinges (see Figure 3). The flexural stiffness modification may be determined by looking at typical bilinear curve of moment-rotation curves of reinforced concrete section.

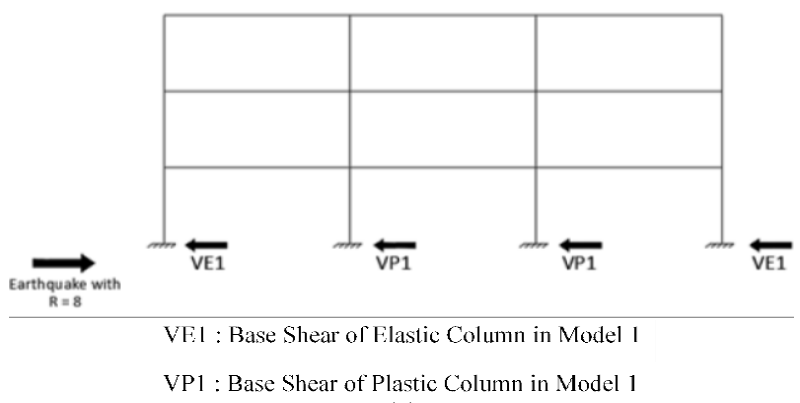

(a)

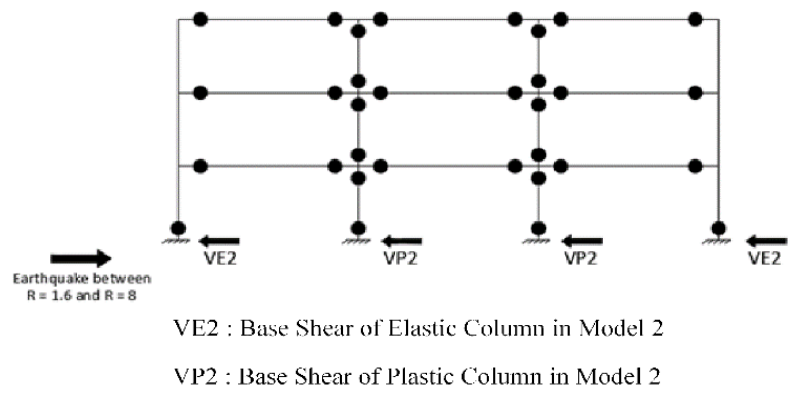

(b)

Figure 2. Design Assumption: (a) Model 1; (b) Model 2

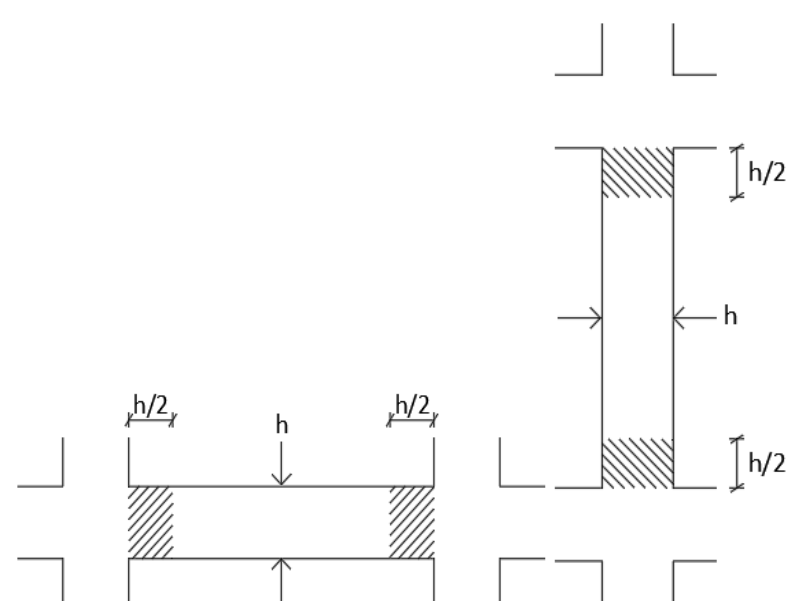

Figure 3. Stiffness Reduction in Model 2 at: (a) Beam; (b) Column

Results from the first model are used to design the beams and plastic columns which may develop plastic damages. Since the columns may experience damages, the strong column weak beam requirement is neglected in this approach. However, the shear design of both beams and columns should still follow the capacity design concept since no shear failure is allowed. Required strengths used for designing the elastic columns are determined by combining the internal forces from both models. It should be noted that the effect of gravity load should only calculated once when combining results from both models. Again, only shear design of the elastic columns should follow standard capacity design approach. The base shear distribution ratio of the structure can be seen in Table 1. The design results of the beams and columns can be seen in Tables 2, 3, and 4 . 
Table 1. Base Shear Distribution Ratio of Elastic Column for (a) 6-Story and (b) 10-Story Building

\begin{tabular}{|c|c|c|c|c|c|}
\hline $\begin{array}{c}\text { Design } \\
\text { Earthquake } \mathrm{X} \\
\text { Direction }\end{array}$ & $\begin{array}{c}\text { Total Base Shear } \\
(\mathrm{kN})\end{array}$ & $\begin{array}{c}\text { Total Base Shear } \\
\text { Elastic Column } \\
(\mathrm{kN})\end{array}$ & \begin{tabular}{|c|} 
Design \\
Earthquake Y \\
Direction \\
\end{tabular} & $\begin{array}{c}\text { Total Base Shear } \\
(\mathrm{kN})\end{array}$ & $\begin{array}{c}\text { Total Base Shear } \\
\text { Elastic Column } \\
\text { (kN) }\end{array}$ \\
\hline Model 1 & 2055.09 & 1013.99 & Model 1 & 1907.64 & 849.24 \\
\hline Model 2 & 3101.46 & 2791.54 & Model 2 & 3096.14 & 2770.44 \\
\hline Total & 5156.55 & 3805.53 & Total & 5003.78 & 3619.68 \\
\hline \multicolumn{2}{|c|}{ Shear Force Distribution Ratio } & $73.80 \%$ & \multicolumn{2}{|c|}{ Shear Force Distribution Ratio } & $72.34 \%$ \\
\hline
\end{tabular}

\begin{tabular}{|c|c|c|c|c|c|}
\hline $\begin{array}{c}\text { Design } \\
\text { Earthquake } \mathrm{X} \\
\text { Direction }\end{array}$ & $\begin{array}{c}\text { Total Base Shear } \\
\text { (kN) }\end{array}$ & \begin{tabular}{|c|} 
Total Base Shear \\
Elastic Column \\
$(\mathrm{kN})$
\end{tabular} & \begin{tabular}{|c|} 
Design \\
Earthquake Y \\
Direction \\
\end{tabular} & $\begin{array}{c}\text { Total Base Shear } \\
(\mathrm{kN})\end{array}$ & $\begin{array}{c}\text { Total Base Shear } \\
\text { Elastic Column } \\
(\mathrm{kN})\end{array}$ \\
\hline Model 1 & 2452.52 & 1513.95 & Model 1 & 2274.09 & 1441.90 \\
\hline Model 2 & 5611.75 & 3998.33 & Model 2 & 5596.76 & 3880.43 \\
\hline Total & 8064.27 & 5512.28 & Total & 7870.85 & 5322.33 \\
\hline \multicolumn{2}{|c|}{ Shear Force Distribution Ratio } & $68.35 \%$ & \multicolumn{2}{|c|}{ Shear Force Distribution Ratio } & $67.62 \%$ \\
\hline
\end{tabular}

(b)

Table 2. Reinforcement Details of 6-Story Building (a) Beam (b) Plastic Column

\begin{tabular}{|c|c|c|c|c|c|c|}
\hline \multirow[b]{2}{*}{ Type } & \multirow[b]{2}{*}{ Dimension } & \multirow[b]{2}{*}{ Position } & \multicolumn{3}{|c|}{ Longitudinal } & \multirow{2}{*}{$\begin{array}{c}\text { Transversal } \\
\text { s }\end{array}$} \\
\hline & & & $\rho$ & Reinforcement & $\begin{array}{l}\text { Strength } \\
\text { Ratio }\end{array}$ & \\
\hline \multirow{2}{*}{ Bl-1 } & \multirow{2}{*}{$300 \times 700$} & Top & $1.04 \%$ & 7019 & 0.91 & \multirow{2}{*}{$2010-110$} \\
\hline & & Bottom & $0.59 \%$ & 4D19 & 0.76 & \\
\hline \multirow{2}{*}{ BI-2 } & \multirow{2}{*}{$300 \times 700$} & Top & $1.04 \%$ & 7019 & 0.98 & \multirow{2}{*}{$2010-110$} \\
\hline & & Bottom & $0.59 \%$ & 4D19 & 0.82 & \\
\hline \multirow{2}{*}{$\mathrm{Bl}-3$} & \multirow{2}{*}{$300 \times 700$} & Top & $0.89 \%$ & 6019 & 0.97 & \multirow{2}{*}{$2010-110$} \\
\hline & & Bottom & $0.44 \%$ & 3019 & 0.93 & \\
\hline \multirow{2}{*}{ BI-4 } & \multirow{2}{*}{$300 \times 700$} & Top & $0.74 \%$ & 5019 & 0.92 & \multirow{2}{*}{$2010-110$} \\
\hline & & Bottom & $0.44 \%$ & 3019 & 0.78 & \\
\hline
\end{tabular}

(a)

\begin{tabular}{|c|c|c|c|c|c|}
\hline \multirow{2}{*}{ Story } & \multirow{2}{*}{ Dimension } & \multicolumn{3}{|c|}{ Longitudinal } & Transversal \\
\cline { 3 - 6 } & & $\rho$ & Reinforcement & $\begin{array}{c}\text { Strength } \\
\text { Ratio }\end{array}$ & S \\
\hline 6 & $350 \times 350$ & $4.51 \%$ & $16 \mathrm{D} 19$ & 0.69 & $2 \mathrm{D} 13-60$ \\
\hline 5 & $350 \times 350$ & $4.51 \%$ & $16 \mathrm{D} 19$ & 0.78 & $2 \mathrm{D} 13-60$ \\
\hline 4 & $400 \times 400$ & $3.36 \%$ & $16 \mathrm{D} 19$ & 0.89 & $3 \mathrm{D} 13-90$ \\
\hline 3 & $450 \times 450$ & $2.60 \%$ & $16 \mathrm{D} 19$ & 0.94 & $3 \mathrm{D} 13-100$ \\
\hline 2 & $450 \times 450$ & $3.90 \%$ & $24 \mathrm{D} 19$ & 0.89 & $3 \mathrm{D} 13-100$ \\
\hline 1 & $500 \times 500$ & $2.59 \%$ & $20 \mathrm{D} 19$ & 0.79 & $3 \mathrm{D} 13-100$ \\
\hline
\end{tabular}

(b)

Table 3. Reinforcement Details of 10-Story Building (a) Beam (b) Plastic Column

\begin{tabular}{|c|c|c|c|c|c|}
\hline \multirow{2}{*}{ Story } & \multirow{2}{*}{ Dimension } & \multicolumn{3}{|c|}{ Longitudinal } & Transversal \\
\cline { 3 - 6 } & & $\boldsymbol{\rho}$ & Reinforcement & $\begin{array}{c}\text { Strength } \\
\text { Ratio }\end{array}$ & s \\
\hline 10 & $350 \times 350$ & $4.96 \%$ & $16 \mathrm{D} 22$ & 0.88 & $2 \mathrm{D} 13-60$ \\
\hline 9 & $350 \times 350$ & $3.72 \%$ & $12 \mathrm{D} 22$ & 0.96 & $2 \mathrm{D} 13-60$ \\
\hline 8 & $400 \times 400$ & $3.80 \%$ & $16 \mathrm{D} 22$ & 0.94 & $3 \mathrm{D} 13-100$ \\
\hline 7 & $400 \times 400$ & $3.80 \%$ & $16 \mathrm{D} 22$ & 0.93 & $3 \mathrm{D} 13-100$ \\
\hline 6 & $450 \times 450$ & $3.00 \%$ & $16 \mathrm{D} 22$ & 0.94 & $3 \mathrm{D} 13-100$ \\
\hline 5 & $450 \times 450$ & $4.50 \%$ & $24 \mathrm{D} 22$ & 0.95 & $3 \mathrm{D} 13-100$ \\
\hline 4 & $500 \times 500$ & $3.65 \%$ & $24 \mathrm{D} 22$ & 0.92 & $3 \mathrm{D} 13-100$ \\
\hline 3 & $500 \times 500$ & $4.86 \%$ & $32 \mathrm{D} 22$ & 0.92 & $3 \mathrm{D} 13-100$ \\
\hline 2 & $600 \times 600$ & $2.11 \%$ & $20 \mathrm{D} 22$ & 0.91 & $3 \mathrm{D} 13-100$ \\
\hline 1 & $600 \times 600$ & $2.96 \%$ & $28 \mathrm{D} 22$ & 0.93 & $3 \mathrm{D} 13-100$ \\
\hline
\end{tabular}

(a)

\begin{tabular}{|c|c|c|c|c|c|c|}
\hline \multirow[b]{2}{*}{ Type } & \multirow[b]{2}{*}{ Dimension } & \multirow[b]{2}{*}{ Position } & \multicolumn{3}{|c|}{ Longitudinal } & \multirow{2}{*}{$\begin{array}{c}\text { Transversal } \\
\mathrm{s}\end{array}$} \\
\hline & & & $\rho$ & Reinforcement & $\begin{array}{l}\text { Strength } \\
\text { Ratio }\end{array}$ & \\
\hline \multirow{2}{*}{ Bl-1 } & \multirow{2}{*}{$300 \times 700$} & Top & $0.89 \%$ & 6019 & 0.91 & \multirow{2}{*}{$2010-110$} \\
\hline & & Bottom & $0.44 \%$ & 3019 & 0.88 & \\
\hline \multirow{2}{*}{ BI-2 } & \multirow{2}{*}{$300 \times 700$} & Top & $1.03 \%$ & 7019 & 0.94 & \multirow{2}{*}{$2010-110$} \\
\hline & & Bottom & $0.59 \%$ & $4 \mathrm{D} 19$ & 0.79 & \\
\hline \multirow{2}{*}{ B1-3 } & \multirow{2}{*}{$300 \times 700$} & Top & $1.18 \%$ & 8019 & 0.93 & \multirow{2}{*}{$2010-110$} \\
\hline & & Bottom & $0.59 \%$ & 4019 & 0.89 & \\
\hline \multirow{2}{*}{ B|-4 } & \multirow{2}{*}{$300 \times 700$} & Top & $0.74 \%$ & 5019 & 0.92 & \multirow{2}{*}{$2010-110$} \\
\hline & & Bottom & $0.44 \%$ & 3019 & 0.74 & \\
\hline \multirow{2}{*}{ BI-5 } & \multirow{2}{*}{$300 \times 700$} & Top & $1.33 \%$ & 9019 & 0.95 & \multirow{2}{*}{$2010-110$} \\
\hline & & Bottom & $0.74 \%$ & 5019 & 0.81 & \\
\hline \multirow{2}{*}{ BI-6 } & \multirow{2}{*}{$300 \times 700$} & Top & $1.48 \%$ & 10019 & 0.95 & \multirow{2}{*}{$2010-110$} \\
\hline & & Bottom & $0.74 \%$ & 5019 & 0.89 & \\
\hline
\end{tabular}

(b)

Table 4. Reinforcement Details of Elastic Column (a) 6-Story Building (b) 10-Story Building

\begin{tabular}{|c|c|c|c|c|c|}
\hline \multirow[b]{2}{*}{ Story } & \multirow[b]{2}{*}{ Dimension } & \multicolumn{3}{|c|}{ Longitudinal } & \multirow{2}{*}{$\begin{array}{c}\text { Transversal } \\
s\end{array}$} \\
\hline & & $\rho$ & Reinforcement & Strength Ratio & \\
\hline 6 & $700 \times 700$ & $3.94 \%$ & $24 D 32$ & 0.98 & $3 D 13-100$ \\
\hline 5 & $700 \times 700$ & $5.25 \%$ & $32 \mathrm{D} 32$ & 0.97 & $3013-100$ \\
\hline 4 & $700 \times 700$ & $5.91 \%$ & $36 \mathrm{D} 32$ & 0.94 & $3013-100$ \\
\hline 3 & $700 \times 700$ & $4.59 \%$ & 28032 & 0.93 & $3013-100$ \\
\hline 2 & $700 \times 700$ & $3.94 \%$ & 24032 & 0.96 & $3 D 13-90$ \\
\hline 1 & $700 \times 700$ & $2.62 \%$ & $16 \mathrm{D} 32$ & 0.99 & $3 D 13-90$ \\
\hline
\end{tabular}

(a)

\begin{tabular}{|c|c|c|c|c|c|}
\hline \multirow{2}{*}{ Story } & \multirow{2}{*}{ Dimension } & \multicolumn{3}{|c|}{ Longitudinal } & Transversal \\
\cline { 3 - 6 } & & $\rho$ & Reinforcement & $\begin{array}{c}\text { Strength } \\
\text { Ratio }\end{array}$ & $\mathbf{s}$ \\
\hline 10 & $900 \times 900$ & $2.48 \%$ & $16 \mathrm{D} 40$ & 0.90 & $4 \mathrm{D} 13-100$ \\
\hline 9 & $900 \times 900$ & $3.10 \%$ & $20 \mathrm{D} 40$ & 0.99 & $4 \mathrm{D} 13-100$ \\
\hline 8 & $900 \times 900$ & $4.96 \%$ & $32 \mathrm{D} 40$ & 0.87 & $4 \mathrm{D} 13-100$ \\
\hline 7 & $900 \times 900$ & $4.96 \%$ & $32 \mathrm{D} 40$ & 0.99 & $4 \mathrm{D} 13-100$ \\
\hline 6 & $900 \times 900$ & $5.58 \%$ & $36 \mathrm{D} 40$ & 0.96 & $4 \mathrm{D} 13-100$ \\
\hline 5 & $900 \times 900$ & $5.58 \%$ & $36 \mathrm{D} 40$ & 0.97 & $4 \mathrm{D} 13-100$ \\
\hline 4 & $900 \times 900$ & $4.96 \%$ & $32 \mathrm{D} 40$ & 0.95 & $4 \mathrm{D} 13-100$ \\
\hline 3 & $900 \times 900$ & $4.34 \%$ & $28 \mathrm{D} 40$ & 0.96 & $4 \mathrm{D} 13-100$ \\
\hline 2 & $900 \times 900$ & $3.10 \%$ & $20 \mathrm{D} 40$ & 0.86 & $4 \mathrm{D} 13-100$ \\
\hline 1 & $900 \times 900$ & $3.72 \%$ & $24 \mathrm{D} 40$ & 0.94 & $4 \mathrm{D} 13-100$ \\
\hline
\end{tabular}

(b) 


\section{Buildings' Performances Analysis}

Analysis is conducted twice for each building to model dominant earthquake in each orthogonal direction (see Figure 4). Performance of the buildings are reported at two levels of earthquakes which are the elastic design response spectrum (EDRS) and maximum considered earthquakes (MCER) which is 1.5 times of EDRS. The buildings are analyzed with nonlinear static procedure (NSP) and nonlinear dynamic procedure (NDP) using SAP 2000 software [8]. The load pattern used in NSP is the first translational mode of the corresponding directions.

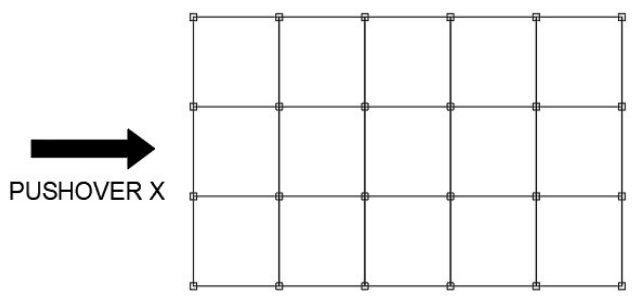

(a)

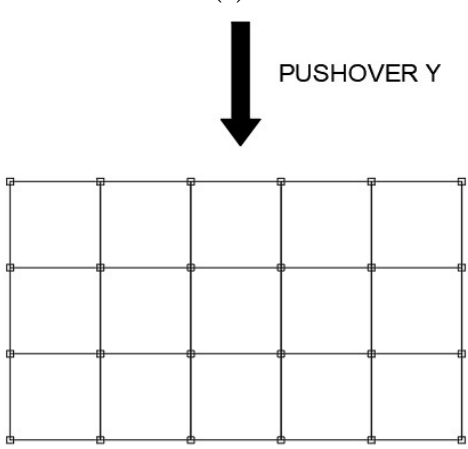

(b)

Figure 4. Nonlinear Static Procedure (NSP) in: (a) Xdirection (b) Y-direction

In NDP analysis, the seismic load used is spectrum consistent ground accelerations generated from $\mathrm{El}$ Centro 18 May 1940 earthquake N-S and E-W components in accordance to Indonesian Seismic Code (SNI 1726:2012 [1]). Two level of acceleration response spectrums to match are the elastic design response spectrum (EDRS) and spectrum correspondding to maximum considered earthquake (MCER). The buildings are subjected to two-directional ground motion which peak ground accelerations ratio (4:3) is taken the same as the original earthquake motion. Illustration of the ground motions used for analysis are presented in Figure 5.

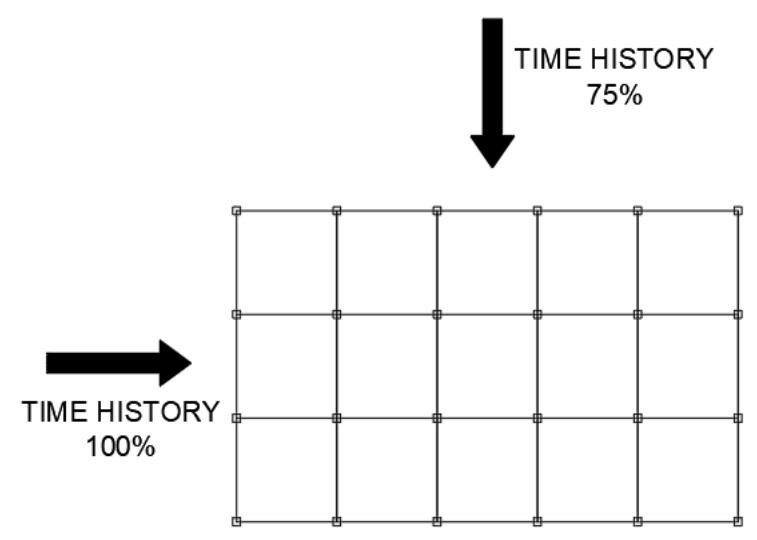

(a)

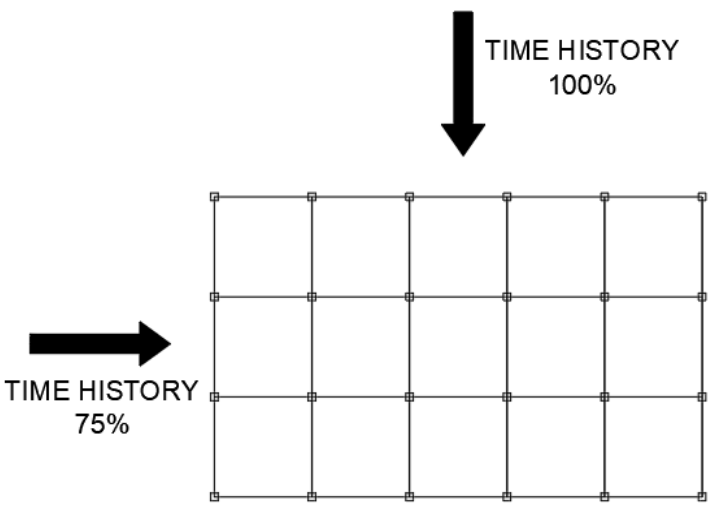

(b)

Figure 5. Nonlinear Dynamic Procedure (NDP) with Dominant Ground Motion in: (a) X-dominant (b) Y-dominant

\section{Analysis Results}

The drifts of the buildings are presented in Figures 6 to 9 . The drifts are plotted against limitation according to FEMA 273 [7], which are $2 \%$ for design earthquake (EDRS) and and $4 \%$ for maximum considered (MCER) earthquake. It can be seen in Figures 6 and 7 , that the 6 -story building performs very well as all drifts satisfy the allowable drift in both directions and both earthquake levels. In X-direction, it is recorded that the maximum drifts are $1.80 \%$ and $2.53 \%$ for EDRS and MCER earthquakes, respectively. While in Y-direction, the drifts are $1.94 \%$ and $2.80 \%$ for EDRS and MCER earthquakes, respectively.

Similar performances are seen at 10 -story buildings that all the drifts meet the requirement by FEMA 273. In Figures 8 and 9, it can be observed that the drifts of the buildings at EDRS and MCER earthquakes are $1.60 \%$ and $2.38 \%$ in X-direction, and $1.65 \%$ and $2.76 \%$ in Y-direction. 


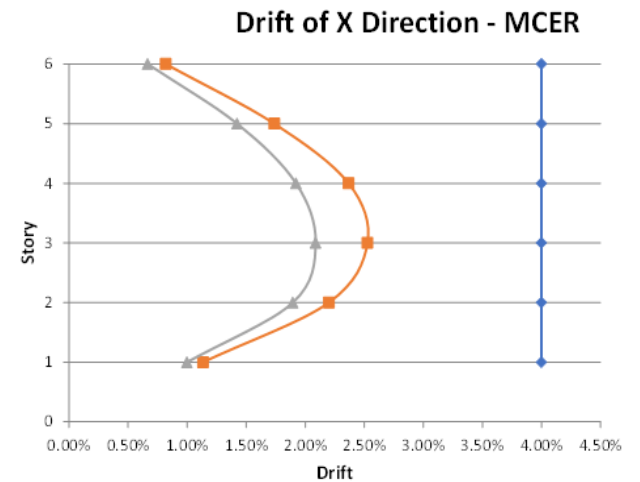

(a)

Drift of Y Direction - MCER

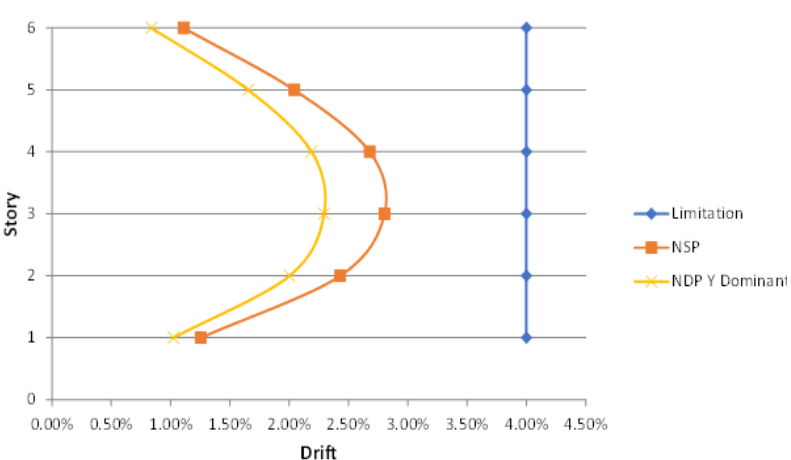

(b)

Figure 7. Drifts of 6-Story Building for MCER in: (a) Xdirection; (b) Y-direction

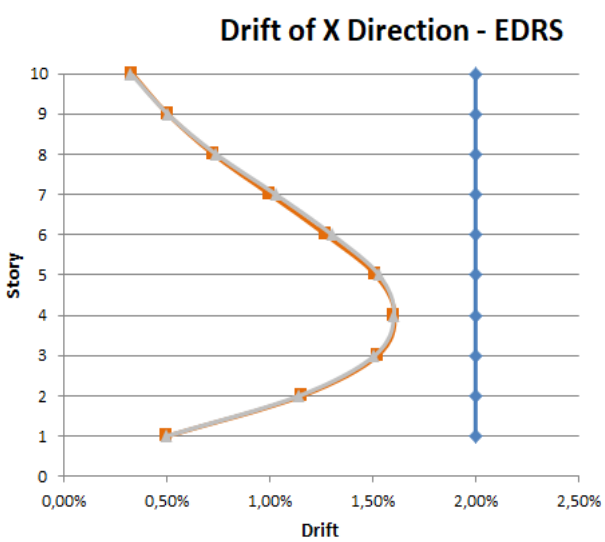

(a)

Drift of $Y$ Direction - EDRS

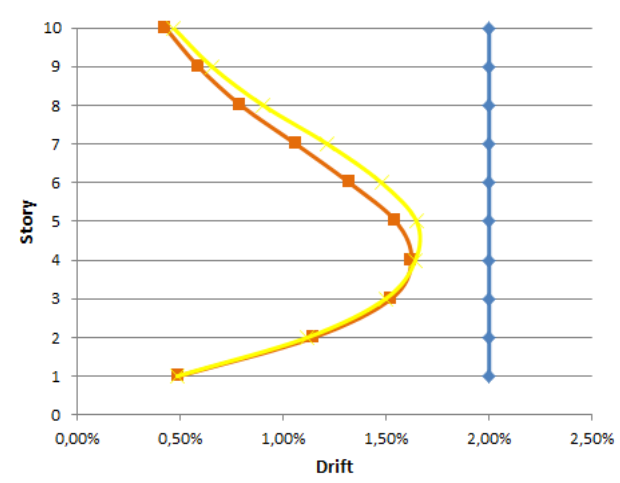

(b)

Figure 8. Drift of 10-Story Building for EDRS in: (a) $\mathrm{X}$ Direction (b) Y Direction

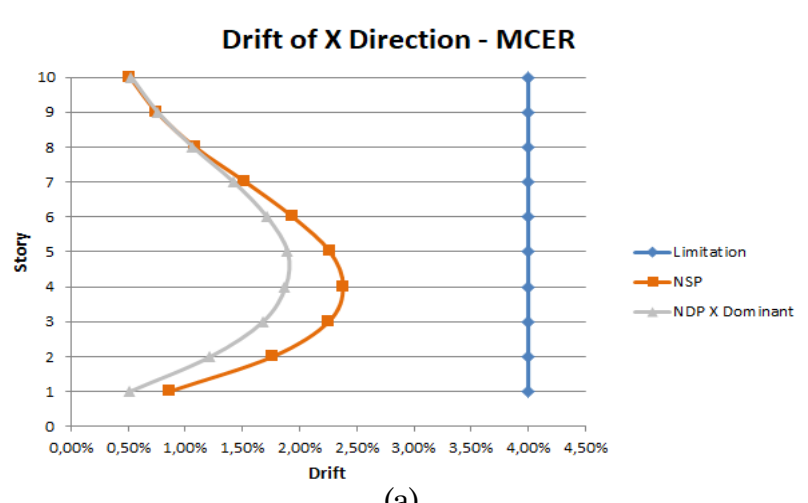

(a)

Drift of Y Direction - MCER

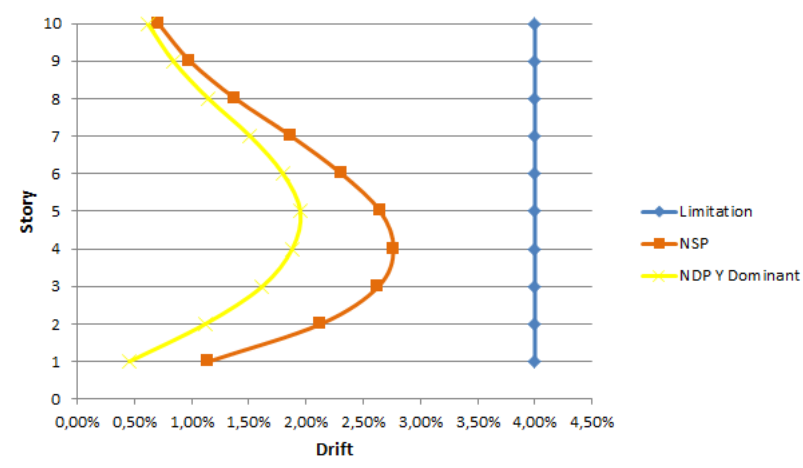

(b)

Figure 9. Drift of 10-Story Building for MCER in: (a) $\mathrm{X}$ Direction (b) Y Direction.

In order to make sure if the buildings have good performance, safe failure mechanism should be investigated. From all variations of the analysis (the number of story, the level of earthquake used for analysis, the analysis procedures, and direction of dominant earthquake), it is observed that there are no plastic damages in the elastic columns which means the structures can resist the earthquakes with safe partial sidesway mechanism. Figures 10 to 13 show typical plastic damages of the frames.

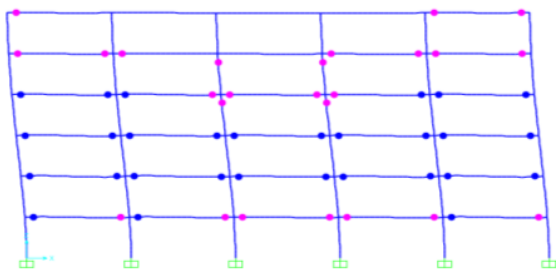

(a)

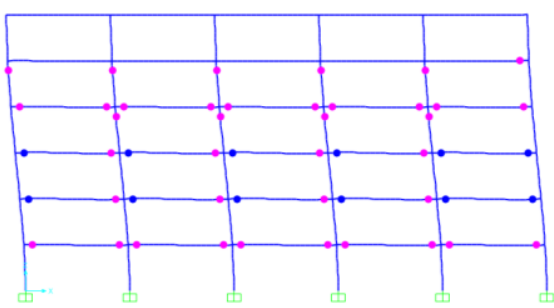

(b)

Figure 10. Plastic Damages of 6-story Building from NSP Analysis with EDRS Earthquake Level in X-direction: (a) Frame 1; and (b) Frame 2 
Moreover, from the analysis results, it can be observed how far the deviation of shear force ratio resisted by the elastic columns. The shear force distribution ratio are presented in Table 5 . In the design stage, this ratio is set approximately $70 \%$ with the assumption that all members experience plastic damages except the elastic columns. Since the actual performance seen in Figures 10 to 13 show less damages, it is logical if the shear force resisted by the elastic columns are less than $70 \%$.

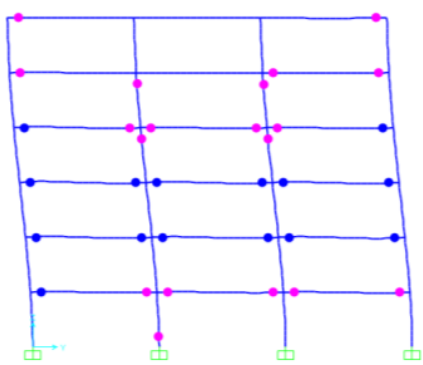

(a)

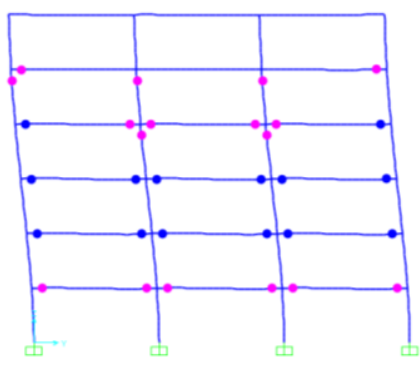

(b)

Figure 11. Plastic Damages of 6-story Building from NSP Analysis with EDRS Earthquake Level in Y-direction (a) Frame A; and (b) Frame C

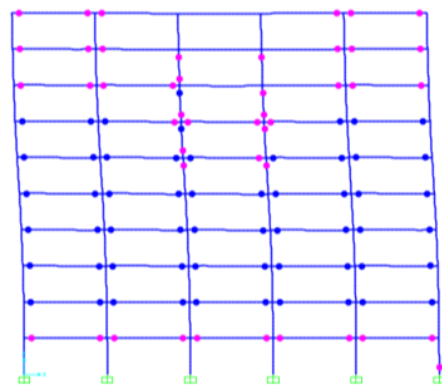

(a)

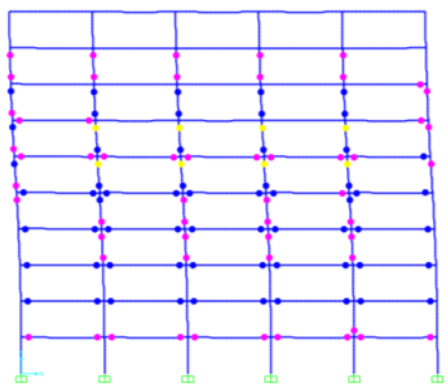

(b)

Figure 12. Plastic Damages of 10-story Building from NDP Analysis with MCER Earthquake Level in X-direction (a) Frame 1; and (b) Frame 2
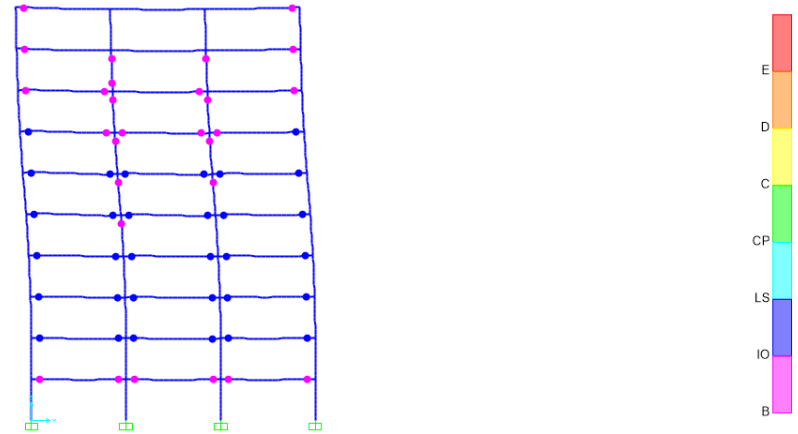

(a)
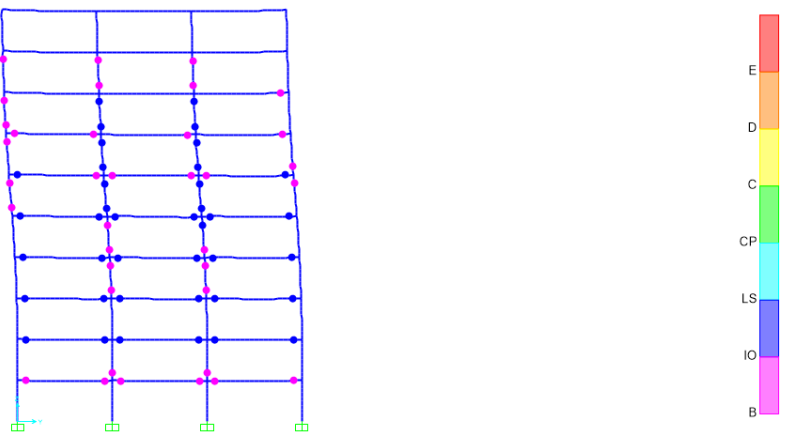

(b)

Figure 13. Plastic Damages of 10-story Building from NDP Analysis with MCER Earthquake Level in Y-direction (a) Frame A; and (b) Frame C

Table 5. Actual Base Shear Distribution Ratio of (a) 6-Story Building and (b) 10-Story Building

\begin{tabular}{|c|c|c|}
\hline & X Direction & Y Direction \\
\hline Design & $73.80 \%$ & $72.34 \%$ \\
\hline Pushover EDRS & $44.77 \%$ & $42.05 \%$ \\
\hline Pushover MCER & $39.92 \%$ & $42.56 \%$ \\
\hline $\begin{array}{c}\text { Time History X } \\
\text { Dominant EDRS }\end{array}$ & $50.63 \%$ & $41.97 \%$ \\
\hline $\begin{array}{c}\text { Time History Y } \\
\text { Dominant EDRS }\end{array}$ & $49.78 \%$ & $48.46 \%$ \\
\hline $\begin{array}{c}\text { Time History X } \\
\text { Dominant MCER }\end{array}$ & $49.54 \%$ & $44.55 \%$ \\
\hline $\begin{array}{c}\text { Time History Y } \\
\text { Dominant MCER }\end{array}$ & $45.29 \%$ & $47.82 \%$ \\
\hline
\end{tabular}

(a)

\begin{tabular}{|c|c|c|}
\hline & X Direction & Y Direction \\
\hline Design & $68.35 \%$ & $67.62 \%$ \\
\hline Pushover EDRS & $59.79 \%$ & $58.72 \%$ \\
\hline Pushover MCER & $51.31 \%$ & $49.93 \%$ \\
\hline $\begin{array}{c}\text { Time History } \\
\text { Dominan X EDRS }\end{array}$ & $59.91 \%$ & $56.50 \%$ \\
\hline $\begin{array}{c}\text { Time History } \\
\text { Dominan Y EDRS }\end{array}$ & $58.17 \%$ & $58.80 \%$ \\
\hline $\begin{array}{c}\text { Time History } \\
\text { Dominan X MCER }\end{array}$ & $59.50 \%$ & $59.35 \%$ \\
\hline $\begin{array}{c}\text { Time History } \\
\text { Dominan Y MCER }\end{array}$ & $59.67 \%$ & $58.95 \%$ \\
\hline
\end{tabular}

(b)

\section{Conclusions}

Based on the seismic performance of 6- and 10-story reinforced concrete building designed by using modified partial capacity design method (M-PCD) with $70 \%$ of base shear distribution ratio, some conclusion may be drawn:

1. The drifts of the observed buildings meet the criteria set by FEMA 273 [7]. The drifts are below $2 \%$ and $4 \%$ limit for design earthquake (EDRS) and maximum considered earthquake (MCER) levels. The drifts of 6 -story building are $1.94 \%$ and 2.80\% for EDRS and MCER earthquake levels. The drifts of 10-story building are $1.65 \%$ and 2.76\% for EDRS and MCER earthquake levels.

2. Both observed buildings can resist up to earthquake with MCER level with partial sidesway mechanism, since no elastic columns experience plastic damages. 
3. The actual base shear distribution ratio in the elastic column with respect to total base shear is less than that on the design stage. This is logical since the frames (excluding the elastic columns) experience less damage compared to assumption in the design stage. This means that the stiffer frame may resist more force and the elastic columns may resist less force.

\section{References}

1. Badan Standarisasi Nasional, SNI-03-1726-2012. Tata Cara Perencanaan Ketahanan Gempa untuk Struktur Bangunan Gedung dan Non Gedung, Jakarta, 2012.

2. Paulay, T. and Priestly, M.J.N., Seismic Design of Reinforced Concrete and Masonry Buildings, John Wiley \& Sons, Inc., New York, 1992.

3. Lumantarna, B., Perencanaan Kapasitas Alternatif, Suatu Studi Pendahuluan, Proceedings of the Conference on Modern Design and Construction for Safety, Economy, and Durability, Petra Christian University, Surabaya, Indonesia, 1994.
4. Muljati, I. and Lumantarna, B., Partial Capacity Design, an Alternative to the Capacity Design Method, Proceedings of the 19th Australasian Conference on the Mechanics of Structures and Materials, ACMSM19, Christchurch, New Zealand, 2007, pp. 409-414.

5. Muljati, I. and Lumantarna, B., Performance of Partial Capacity Design on Fully Ductile Moment Resisting Frame in Highly Seismic Area in Indonesia, The Eleventh East Asia-Pacific Conference on Structural Engineering and Construction (EASEC-11), Taipei, November, 2008.

6. Tanaya, L.S., Metode Modified Partial Capacity Design (M-PCD), (Unpublished Thesis), Universitas Kristen Petra, Surabaya, Indonesia, 2021.

7. Federal Emergency Management Agency 273, NEHRP Guidelines for the Seismic Rehabilitation of Buildings, Washington, D.C., USA, 1997.

8. CSI Analysis Reference Manual for SAP2000, ETABS, SAFE and CSIBridge, Computer \& Structure, Inc., 2017.

9. Badan Standarisasi Nasional, SNI-03-2847-2013, Persyaratan Beton Struktural untuk Bangunan Gedung, Jakarta, 2013. 